\title{
Tablets (iPad) for M-Learning in the Context of Social Constructivism to Institute an Effective Learning Environment
}

\author{
http://dx.doi.org/10.3991/ijim.v8i1.3452 \\ P. Thinley, J. Reye and S. Geva \\ Queensland University of Technology, Brisbane, Australia
}

\begin{abstract}
With the proliferation of mobile devices, educational institutions have experimented with various mobile devices to implement mobile learning (M-Learning). Mobile devices have been used to facilitate, support, and enhance and extend the reach of teaching and learning. Although there are very few empirically evaluated studies on MLearning projects, these studies reported that mobile devices brought a transformation to the educational process. To be able to view M-Learning as a rich, collaborative and conversational experience, whether in the classroom or outside we need good mobile applications. Studies have revealed that effective learning happens when teachers and learners are actively participating in the knowledge building process. Therefore, there is a need for applications that create effective learning environments which are learnercentred, knowledge-centred, assessment-centred and community-centred.
\end{abstract}

Index Terms-M-Learning, Tablets, Social Constructive Learning.

\section{INTRODUCTION}

With the proliferation of mobile devices, educational institutions have experimented with various mobile devices to implement mobile learning (M-Learning). Mobile devices have been used to facilitate, support, and enhance and extend the reach of teaching and learning. But, use of mobile devices has not moved further than when it was first adopted for M-Learning. It has been used to provide and access mere information, rather than knowledge.

Unlike the other learning activities, mobile learning started with the assumption that learners are always on the move from physical location to location, learning topics. Studies have reported that students learn effectively when they actively participate in learning. And in a mobile learning environment, learners are active as they initiate their learning activities and control their own educational progress and outcomes. Therefore, mobile learning has been predicted to bring great transformations to the traditional mode of learning and outcomes.

Although there are very few empirically evaluated studies on M-Learning projects, these studies reported that mobile devices brought a transformation to the educational process. As reported in EDUCAUSE 2011, MLearning is still in need of distinct frameworks or models for using and developing mobile applications for learning. Without a proper framework, it would be challenging to evaluate outcomes from any M-Learning projects.
As M-Learning has been conceptualised with the assumption that learners are always on the move, MLearning has been viewed as an isolated activity. To be able to view M-Learning as a rich, collaborative and conversational experience, whether in the classroom or outside we need good mobile applications. These mobile applications can act as a platform on which an effective learning environment can be created.

Tablets with more advanced features (iPad, Samsung Galaxy, etc.) have been widely embraced by universities. They have become popular educational devices because of the availability of significant number of educational applications. There are apps available ranging from study aids to collaborative and interactive learning apps. Most of these applications support traditional learning activities instead of enhancing them.

Applications that are available have demonstrated behaviourist, constructivist and collaborative perspectives of learning theory. Studies have revealed that effective learning happens when teachers and learners are actively participating in the knowledge building process. Therefore, there is a need for applications that create effective learning environments which are learner-centred, knowledge-centred, assessment-centred and communitycentred.

\section{M-LEARNING}

M-Learning is defined as a form of learning accomplished with the use of mobile technology. Mobile devices that made their way into the hands of students and teachers include laptops,tablet-PCs,smart-phones and personal digital assistants (PDAs). Recently tablets havebeen added tothegrowing list of mobile devices used for teaching and learning purposes. Educational institutions have started adopting tablets because they are portable and the WiFi connectivity makes access to learning resources, communication, and collaboration, more convenient. Tablets are observed to be more suitable M-Learning devices because of their bigger display screens and advanced technological features.

Teaching and learning environments have used mobile devices to demonstrate technological feasibility and pedagogical opportunity [17]. The US National Research Council produced a synthesis of research into educational effectiveness and they concluded that students learn effectively when the learning environment is learnercentred, knowledge-centred, assessment-centred and community-centred [14]. These research findings match the social-constructivist approach of learning where stu- 
dents play an active role in a learning context and teachers and students collaborate to facilitate knowledge construction.

\section{SOCIAL CONSTRUCTIVISM AND M- LEARNING}

Social constructivism in education is when learners are encouraged to interact and participate in learning to construct, transfer and share knowledge effectively. Studies [5] and [18], have reported numerous advantages of increasing classroom engagement and participation. It is stated that discussions helped improve students' ability to test their ideas, collaborative skills, improve problem solving skills and also build deeper understanding of what they are learning. By adopting mobile technologies for teaching and learning, it has been expected to exploit the social-constructivist pedagogical approaches to learning.

Computer-supported collaborative learning (CSCL) is a pedagogical approach where learning is characterized by the sharing and construction of knowledge among learners using technology as primary means of communication and it is grounded in social constructivism.

To support teaching and learning process effectively we need to integrate the technological capabilities available in a way that enhances teaching and learning process instead of just replacing the traditional form teaching and learning. Laurillard's [8] "Conversational Framework" has been developed based on several learning theories (instructional, constructivism, social constructivism), in which communication in any direction between teachers and learners is seen as central to learning process. Numerous studies have reported that discussion, interaction and reflection during the learning process provide positive learning outcome [5], [18]. Therefore, "Conversational Framework" can be used to test the value of MLearning technologies and also to ensure that these technologies enhance teaching and learning.

\section{A. Expectations of Mobile Devices in Education}

The use of mobile devices in educational institutions had great expectations from both teachers and students. It was expected to change the didactic traditional classroom learning to a more active and engaging learning environment, as reported in EDUCAUSE report 2011. According to the survey conducted by EDUCAUSE, students expected to use mobile devices in the following areas:
i. General Communication
ii. Instruction
iii. Administration
iv. Research

Institutions have reported their readiness and priority in deploying the following mobile services:
i. Web presence
ii. Learning/course management service
iii. Library catalogue and library services
iv. Student recruitment and admissions
v. Administrative services for student information

Most universities are ready with infrastructure as well as with human resources to adopt M-Learning and provide mobile learning applications. EDUCAUSE report 2011 also reported that the mobile devices will enable great opportunities in delivering course content and relat- ed teaching/learning activities. Students' responses to the EDUCAUSE survey also highlighted that they would value mobile applications that help in coordination of students and learning resources, and also applications to enhance pedagogical activities that integrate into the learning process.

But in reality, Litchfield, Dyson, Lawrence, and Zmijewska [9], reported that the majority of M-Learning projects have focused on improving interactivity in the classroom or on ubiquitous learning, i.e. increasing students' access to learning materials anytime anywhere. Therefore, mobile devices have been used to replicate the traditional teaching and learning techniques when it can be used for more than just information delivery and retrieval in education. Studies [5] and [18] have reported that effective learning happens when there is constant communication among the peers as well as between learner and teacher. These communications can take place in the form of asking question, receiving response, peer-discussion and feedback. Therefore, to make effective use of mobile technology for teaching and learning, its use can be evaluated using the "Conversational Framework".

\section{B. Trends of Mobile Use in Higher Education}

Zeng and Luyegu [22] reported that the combination of wireless technology and mobile computing has resulted in escalated transformations in the educational world. However, in 2010 some of the researchers were still predicting that mobile and wireless communication technology could play an important role in the revolution of education [10]. This clearly indicates that the use of mobile and wireless communication technology for learning and teaching has not been evaluated and its impact in higher education learning has not been formally reported either. It might not have been reported firstly, because frameworks for using and development of mobile applications are still not clearly defined. Secondly,mobile computing in higher education still remains at a nascent level for many institutions, as reported in EDUCAUSE's 2011 report.

Mobile devices are largely being used for delivering information and barely being used to actively engage students in the learning process. Uses of mobile device for learning as reported by various studies are described below. It is not clear whether these devices have been used in pedagogical appropriate ways.

Mobile phones with their restricted screen size have limited their use to sending SMS (Short Messaging Service) messages, with prompts for course requirements, assignment due dates, polling answers for quizzes, and sending URL links to additional learning resources.

Tablet PCs have been used in the classrooms as a digital whiteboard to present lecture slides. Additionally, with software products such as Microsoft OneNote, PowerPoint, and Journal, instructors are able to write on the digital whiteboard as they would do on a traditional blackboard [1], [19]. Such devices have also been used to take notes, read electronic books, and for in-class assessments, with the use of systems such as Lecturer's Assistant, Class Presenter System, Classroom Learning Partner, etc.

There are diverse reports regarding the impact of these mobile devices on student learning. For example, Cavus 
and Uzunboylu [3] reported that mobile devices promoted critical thinking, while Chao and Chen's [4] study revealed that there was no significant difference in knowledge retention when student used mobile devices. Nevertheless, mobile devices in general have made communication and learning materials accessible anytime and anywhere. Even more so, with technologically advanced mobile devices like tablets that are now available.

\section{TABLETS FOR EDUCATION}

Tablets such as iPads have been designed and developed primarily as an interactive content consumption device which allows multi-touch experience. It provides a platform for audio visual media including books, periodicals, movies, music, games, and web content. Though the iPad was never specifically developed as an educational tool, educational institutions have widely started adopting iPads in classrooms, as a teaching and learning tool to take advantage of its advanced attributes. Its' Wi-Fi and $3 \mathrm{G}$ connectivity allows the user to experience just-in-time learning opportunities, connection and convergence to other devices, networks and technologies. Thereby, studentsand teachers are not restricted to traditional limitations of time and space related to learning.

Other mobile devices have been used for learning but have limitations such as small screen sizes, lack of data inputcapability, short battery life, limited processing power, and low storage capacity. Tablets have been used as mobile learning devices and they can be promising MLearning devices, if they are effectively integrated into teaching and learning environments, to support socialconstructivist pedagogies.

\section{A. iPad for Teaching and Learning}

Many universities worldwide have discussed and reported on the general uses of the iPad but none of the universities have determined a significant pedagogical use of the device in higher education. Student and teachers have used iPad to take notes, listen to lecture recording and browse web for additional learning materials but they have not been used to improve engagement and interaction in a formal learning environment. Additionally, the universities have not yet formally measured the impact of the iPad for general use in teaching and learning contexts.

Universities have adopted the iPad as a collaborative tool, a standardized mobile device to integrate into curriculum. Stanford University of Medical Science, Seton Hill University, Universityof Adelaide and several other universities around the world have distributed iPads to incoming class of students as early on as 2010. The core goals of these projects were to improvethe student learning experience and also to replace traditional textbooks and other teaching materials with online study tools. On the contrary Macquarie University has been cautious in adopting the iPad as a standard tablet device. The university has kept its option open to differenttablet PCs expected to be released in 2011. These universities have adopted the iPad but they have not yet formally measured and reported the effectiveness of the iPad as a tool to enhance teaching and learning

\section{B. Impact of iPad in Education}

All the technologies that have been adopted for teaching and learning purposes have merely digitized what was available before rather than offering more unique, dynamic and engaging pedagogies (Rudd, 2011). Therefore, Tablets such as the iPad the capacity to be adopted as a teaching and learning tool that supports active learning pedagogical approaches.

Many universities adopted iPads in their curriculum with the expectation of improving the teaching and learning experience. It can be observed from iPad projects carried out in the universities, that the iPad has been effectively used as a content delivery device, complementing other forms of conventional content delivery methods. The University of Minnesota, Stanford University, the University of California-Irvine and the University of Central Florida are some of the medical schools that have handed iPads to students for electronic learning. These iPads were equipped with productivity, content delivery, and content consumption apps, such as $\mathrm{Hu}-$ manAnatomy, Epocrates, MedCalc, PDF Reader, and iAnnotate.

There are various reports released by the universities on iPad pilot projects or iPad study programs conducted in those universities. These reports focus primarily on the potential of the iPad as an eReader. Additionally, some universities such as the University of San Francisco have concluded that the iPad has limitations on its use as an effective instructional tool [2].

Furthermore, the medical school of Stanford University has conducted an iPad project and reported that the use of the iPad did not significantly contribute to increased student learning outcomes. But these universities have left it to the students to explore the use of the iPad for learning, instead of the faculty integrating the device in the design of their teaching and learning activities.

According to Perkins [17], learners do not just take in and store the information given; they interpret, elaborate, and test these elaborations, which lead to social constructive learning. Based on the number of universities eagerly adopting the iPad as an eReader, uses of the iPad can be further explored to support this social constructive nature of learning, by integrating it into the teaching andlearning process in the classroom.

\section{TAXONOMY OF EDUCATIONAL APPS}

Students and teachers have used numerous educational apps that are available on the Apple appstore (www.apple.com/au/ipad/from-the-app-store/) and some of the universities have even developed their own apps. The following taxonomy of educational applications has been developed to classify apps used for formal learning. In this context, formal learning is defined as learning where a university/department sets the goals and objectives of learning [6].

These categories developed by the authors have been chosen after analyzing applications that are (or have been) used by the students and teachers in higher education. These educational apps ranged from interactive study aids to productivity apps. Each category is further described below.

i. Content Consumption and Creation Applications

ii. Content Delivery Applications

iii. Collaborative and Interactive Learning Applications

iv. Course Management Applications 
v. Teaching and Learning Enhancement Applications

\section{A. Content Consumption and Creation Applications}

Students and teachers have used these applications to read, take notes, concept map their ideas, create presentations, draw diagrams, and make use of spreadsheets to capture and analyse tabular data sets. These applications have helped learners and teachers to organize their learning materials but they have not significantly contributed to improvement of student learning outcomes.

\section{B. Content Delivery Applications}

This category of applications is used to enhance the delivery of lectures and distribute podcasts of the lectures and discussions. These applications are used to make the lectures more dynamic, by enabling writing on the slides as would occur on a traditional blackboard. This category of application made lecture presentation dynamic and exciting, therefore its use have been restricted to lecture delivery and presentation.

\section{Collaborative and Interactive Learning Applications}

Lecturers use this category of applications to encourage students to engage, participate in the lecture that isbeing delivered, and provide them with platforms to collaborate and learn. This category of applications includes applications that encourage any kind of communication among teachers and students, including classroom polling applications, as they help in initiating classroom discussion.

\section{Course Management Applications}

Applications that universities use for administration purposes such as unit enrolment, class allocations, unit tracking, grade management, and to manage lecture and course content. Some of the universities have developed custom applications for course management, while most universities use Blackboard Mobile ${ }^{\mathrm{TM}}$ application. Course Management Applications have made managing and organizing courses more efficient.

\section{E. Teaching and Learning Enhancement Applications}

These applications are used by teachers and students to support teaching and learning activities. These applications include file management applications that help people organise their files as the iPad does not have a file management system.

\section{TABLET APPLICATIONS AND LEARNING THEORIES}

In Table I, the above categories are compared with the classification of mobile learning activities developed by Naismith et al. (2004). These authors have categorized activities around existing relevant learning theories.

Some iPad projects [3] and [9] have reported that the use of the iPad did alter academic workflows, such as making them paperless, making web resources more easily accessible to gather information, making it easier to handle notes, making marking more portable, and being able to listen to podcasts anytime [9], [13] and [14]. Though the iPad has received positive response as an educational technology tool, it has not yet accomplished the expectations of students that were highlighted in EDUCAUSE 2011 report.
TABLE I.

APPLICATION TAXONOMY WITH RELEVANT LEARNING THEORIES

\begin{tabular}{|c|c|c|}
\hline $\begin{array}{l}\text { Mobile Appli- } \\
\text { cation Catego- } \\
\text { ry }\end{array}$ & $\begin{array}{l}\text { Example Mobile } \\
\text { Applications }\end{array}$ & $\begin{array}{l}\text { Learning Theo- } \\
\text { ry }\end{array}$ \\
\hline $\begin{array}{l}\text { Content Con- } \\
\text { sumption and } \\
\text { Creation }\end{array}$ & $\begin{array}{l}\text { Consumption: } \\
\text { inkling, Good- } \\
\text { Reader, iAnnotate } \\
\text { Creation: Quick } \\
\text { Graph, EverNote, } \\
\text { Popplet , Auto- } \\
\text { CAD WS }\end{array}$ & $\begin{array}{l}\text { Some of these } \\
\text { apps have quiz- } \\
\text { zes so the par- } \\
\text { tially support } \\
\text { Behaviorist } \\
\text { learning theory }\end{array}$ \\
\hline $\begin{array}{l}\text { Content Deliv- } \\
\text { ery }\end{array}$ & $\begin{array}{l}\text { KeyNote, Speak- } \\
\text { erNote Lite, Pod- } \\
\text { casts, Syncpad }\end{array}$ & $\begin{array}{l}\text { Constructivist } \\
\text { learning theory }\end{array}$ \\
\hline $\begin{array}{l}\text { Collaborative } \\
\text { and Interactive } \\
\text { Learning }\end{array}$ & $\begin{array}{l}\text { Edmodo, Word- } \\
\text { Press, iClicker, } \\
\text { iResponseConvore, } \\
\text { tweet and Post-it } \\
\text { PopNotes }\end{array}$ & $\begin{array}{l}\text { Behaviorist } \\
\text { learning theory } \\
\text { Collaborative } \\
\text { Learning }\end{array}$ \\
\hline $\begin{array}{l}\text { Course Man- } \\
\text { agement }\end{array}$ & $\begin{array}{l}\text { Blackboard Mo- } \\
\text { bile }{ }^{\mathrm{TM}} \text { and respec- } \\
\text { tive university } \\
\text { applications }\end{array}$ & Not Applicable \\
\hline $\begin{array}{l}\text { Teaching and } \\
\text { Learning En- } \\
\text { hancement }\end{array}$ & $\begin{array}{l}\text { Splashtop Remote } \\
\text { Desktop, iDown- } \\
\text { load Pro, Air Shar- } \\
\text { ing, DropBox }\end{array}$ & Not Applicable \\
\hline
\end{tabular}

As mentioned above, that report showed that students would value mobile applications that help in coordination of learners and learning resources, and applications to enhance pedagogical activities that integrate into the learning process. The educational applications that are available demonstrate that iPads have just been used to replace traditional modes of teaching and learning. They have indeed made learning and teaching efficient, but there are no formal reports on being able to create effective learning environments.

Therefore, universities need to develop applications that make the learning environment learner-centered, knowledge-centred, assessment-centred and communitycentred. This learning environment would then match the social-constructivist approach to learning, where students play an active role in their learning, and teachers and students collaborate to facilitate knowledge construction.

\section{CONCLUSION}

Educational institutions have experimented with almost every available mobile device, to enhance and to make learning more effective. The tablet is the latest technology that universities have started adopting. The availability of numerous educational applications for the tablet gives it an edge over all the other mobile devices. 
Educational applications that are available demonstrate behaviorist, constructivist and collaborative perspectives of the learning theory. From the taxonomy presented above, it can be seen that most of these applications are used to support teaching and learning activities.

From the available educational applications, none of the applications demonstrate the social constructivist perspective of learning theory. There are few applications that provide interactive and collaborative pedagogy. Studies report that students learn when they are active participants in the learning process. Therefore, to make the most of the tablet, there is a need for educational applications that can capitalize on the benefits of effective learning pedagogies.

\section{REFERENCES}

[1] Anderson, R., Anderson, R., Davis, K. M., Linnell, N., Prince, C., and Razmov, V. (2007). "Supporting active learning and example based instruction with classroom technology." In Proceedings of the 38th ACM Technical Symposium on Computer Science Education, 69-73, Covington, Kentucky, USA.

[2] Bansavich, J. C. (2011). iPad study at usf [Online]. Available: http://ipad.wiki.usfca.edu/file/view/iPad+Study+at+USF+Report.p df.

[3] Belanger, Y. (2011). "The Duke Digital Initiative - 2012 Update." [Online]. Available: http://cit.duke.edu/wp-content/uploads/2010/ 08/DDI-2012-Report.pdf.

[4] Cavus, N., \& Uzunboylu, H. (2009).Improving critical thinking skills in mobile learning. Procedia Social and Behavioral Sciences, 1, 434438. http://dx.doi.org/10.1016/j.sbspro.2009.01.078

[5] Chao, P.Y., \& Chen, G.D. (2009).Augmenting paper based learning with mobile phones. Interacting with Computers, 21, 173185.

http://dx.doi.org/10.1016/j.intcom.2009.01.001

[6] Cofer, D. (2000). "Informal Workplace Learning. Practice Application Brief." NO 10. U.S. Department of Education: Clearinghouse on Adult, Career, and Vocational Education.

[7] Corden, R.E. (2001). Group discussion and the importance of a shared perspective: Learning from collaborative research. Qualitative Research, 1(3), 347-367. http://dx.doi.org/10.1177/ 146879410100100305

[8] Eichenlaub, N., Gabel, L., Jakubek, D., McCarthy, G., and Wang, W. "Project iPad: Investigating Tablet Integration in Learning and Libraries at Ryerson University." Computer in Libraries 31(7): 17-22 [Online]. Available: http://www.infotoday.com/cilmag/ sep11/Eichenlaub Gabel Jakubek McCarthy Wang.shtml.

[9] Hardy, B. and Suter, T. (2011). "iPad Pilot Summary and Course Summary." [Online]. Available: http://www.janhylen.se/wpcontent/uploads/2012/10/ipad research memo Oklahoma.pdf.

[10] Laurillard, D. (2002). Rethinking University Teaching. A conversational framework for the effective use of learning technologies. London: $\quad$ Routledge $\quad$ ISBN $\quad 0415256798$. http://dx.doi.org/10.4324/9780203304846

[11] Litchfield, A., Dyson, L. E., Lawrence, E., and Zmijewska, A. (2007). "Directions for m-learning research to enhance active learning." [Online]. Available: http://www.ascilite.org.au/ conferences/ singapore07/ procs/ litchfield.pdf.
[12] Liu, G. Z., and Hwang, G. J. (2010). "A key step to understanding paradigm shifts in e-learning: Towards context-aware ubiquitous learning." British Journal of Educational Technology 41(2): E1E9. http://dx.doi.org/10.1111/j.1467-8535.2009.00976.x

[13] Marmarelli, T. (2011). "The Reed College iPad Study." [Online]. Available: www.reed.edu/cis/about/ipad_pilot/Reed_ipad_report.pdf.

[14] Murray, O. T., and Olcese, N. R. (2011). "Teaching and Learning with iPads, Ready or Not?.” TechTrends, 55(6): 42-48 [Online]. Available: https://dl-web.dropbox.com/get/iPad\%20Projects/ Pensylvania\%20University.pdf?w=AADlErKhR1GNq10gVskpolA541Jbw X9cuZakK-2QKHGbDw.

[15] Naismith, L., Lonsdale, P., Vavoula, G., and Sharples, M. (2004). "Literature review in mobile technologies and learning." Birmingham: NestaFuturelab.

[16] National Research Council. (1999). How People Learn: Brain, Mind, Experience, and School.Washington, DC: National Academy Press.

[17] Perkins, D.N. (1991). Technology Meets Constructivism: Do They Make a Marriage? Educational Technology.

[18] Sharples, M., Taylor, J., and Vavoula, G. (2005). "Towards a theory of mobile learning." Paper presentated at the mLearn 2005 4th World conference on mLearning, Cape Town. Available: http://www.mlearn.org.za/papers-full.html.

[19] Taylor, J., and Evans, D. (2005). Pulling together: Keeping track of pedagogy, design and evaluation through the development of scenarios-A case study. Learning, Media and Technology, 30(2), 131-145. http://dx.doi.org/10.1080/17439880500093588

[20] Weber, K., Maher, C., Powell, A., \& Lee, H.S. (2008). Learning opportunities from group discussions: Warrants become the objects of debate. Educational Studies in Mathematics, 68 (3), 247261. http://dx.doi.org/10.1007/s10649-008-9114-8

[21] Willis, C. L., and Miertschin, S. L. (2004). "Tablet pc's as instructional tools or the pen is mightierthan the 'board!" In Proceedings of the 5th conference on Information technology education,pages 153-159, Salt Lake City, UT, USA. ACM.

[22] Zeng, R., and Luyegu, E. (2012). "Mobile Learning in Higher Education." In A. Olofsson, \& J. Lindberg (Eds.), Informed Design of Educational Technologies in Higher Education: Enhanced Learning and Teaching (pp. 292-306). Hershey, PA: Information Science Reference. http://dx.doi.org/10.4018/978-1-61350-080$\underline{4 . \operatorname{ch} 015}$

\section{AUTHORS}

P. Thinley is with the Electrical Engineering and Computer Science School, Queensland University of Technology, Brisbane, Australia (e-mail: palmo.thinley@ student.qut.edu.au).

J. Reye, is with the Electrical Engineering and Computer Science School, Queensland University of Technology, Brisbane, Australia (e-mail: j.reye@ qut.edu.au).

S. Geva is with the Electrical Engineering and Computer Science School, Queensland University of Technology, Brisbane, Australia (e-mail: s.geva@qut.edu.au).

This article is an extended and modified version of a paper presented at the 5th International Conference on Computer Supported Education (CSEDU 2013), 6-8 May 2013, Aachen, Germany. Submitted 01 December 2013. Published as re-submitted by the authors 05 January 2014. 